\title{
Perbandingan Nilai APGAR Bayi yang Lahir melalui Sectio Caesarea dengan Anestesia umum dan Anestesia Spinal dari Ibu Eklampsia di RSUP Dr. M. Djamil Padang
}

\author{
Angga Kesumah¹, Rini Rustini², Roslaili Rasyid ${ }^{3}$
}

\begin{abstract}
Abstrak
Pemilihan anestesia yang digunakan untuk pasien eklampsia masih menjadi kontroversi. Teknik anestesia spinal atau anestesia umum pada seksio sesarea dapat menpengaruhi luaran neonatus. Tujuan: Membandingkan nilai APGAR neonatus yang lahir melalui sectio caesarea antara anestesia umum dan anestesia spinal pada ibu eklampsia. Metode: Jenis penelitian ini adalah analitik dengan desain cross sectional. Sampel adalah 63 pasien yang dibagi menjadi dua kelompok, yaitu kelompok yang mendapat anestesia spinal sebanyak 30 dan anestesia umum sebanyak 33. Data diperoleh dari rekam medik RSUP Dr. M. Djamil Padang periode Januari 2015 sampai Desember 2018. Data dianalisis dengan uji Kolmogorov-Smirnov. Hasil: Pada menit pertama asfiksia (APGAR1<7) terjadi pada 12 (40\%) neonatus kelompok spinal dan 32 (97\%) neonatus kelompok umum. Sementara itu, pada menit kelima asfikasia (APGAR5<7) terjadi pada $5(16,7 \%)$ neonatus kelompok spinal dan $18(54,5 \%)$ neonatus kelompok umum. Terdapat perbedaan nilai APGAR yang bermakna dengan nilai $p<0,01$ pada menit pertama dan $p=0,02$ pada menit kelima $(p<0,05)$. Simpulan: Penggunaan anestesia spinal untuk sectio caesarea pada ibu eklampsia memberikan luaran nilai APGAR yang lebih baik dibandingkan dengan penggunaan anestesia umum.
\end{abstract}

Kata kunci: nilai APGAR, sectio caesarea, anestesia, eklampsia

\section{Abstract}

The choice of anestesia cesarean section between spinal and general anestesia remains controversial. Spinal anestesia and general anestesia techniques in cesarean section lead to different neonates outcome. Objectives: To compared neonates APGAR scores in cesarean section between general anestesia and spinal anestesia in women with eclampsia. Methods:This research was analytical research with cross sectional design. Samples were 63 patients that were divided into two group, general group and spinal group. Data was obtained from the medical record at RSUP Dr. M. Djamil Padang between the period from January in 2015 until December in 2018. Kolmogorov-smirnov test was used to analyze the data. Results: APGAR score at 1 minute after delivery in the spinal anestesia group showed 12 (40\%) neonates was asphyxia whereas the general anestesia group gave 32 (97\%), while it was 5 (16,7\%) and 18 (54,5\%) neonates in spinal group and general group was asphyxia at 5 minute after delivery, Kolmogorov-smirnov test was significant for all APGAR score with $p<0,01$ at 1 minute and $p=0,02$ at 5 minute $(p<0,05)$. Conclusion: There was a significant difference between the APGAR score at first and fifth minute between spinal group and general group on eclampsia patient. Spinal group has greater APGAR score than general group.

Keywords: APGAR score, sectio caesarea, anestesia, eclampsia

Affiliasi penulis: 1. Prodi Pendidikan Dokter, Fakultas Kedokteran, Universitas Andalas, Padang, Indonesia. 2. Bagian Anestesiologi, Fakultas Kedokteran, Universitas Andalas, Padang, Indonesia. 3. Bagian Mikrobiologi, Fakultas Kedokteran, Universitas Andalas, Padang, Indonesia.
Korespondensi: Rini Rustini, Email: rini.ummukhalid@gmail.com Telp: 081268600862 


\section{PENDAHULUAN}

Hipertensi merupakan komplikasi yang paling umum terjadi pada kehamilan dan merupakan penyebab utama morbiditas dan mortalitas maternal dan perinatal. Hipertensi selama kehamilan dapat berada pada 1 dari 4 macam proses penyakit ini; hipertensi kronis, hipertensi gestasional, preeklampsiaeklampsia, dan hipertensi kronis superimposed dengan preeklamsia. $^{1,2}$ Eklampsia adalah suatu preeklampsia berat yang diikuti oleh kejang, sedangkan yang dimaksud dengan preeklampsia adalah peningkatan tekanan darah yang timbul setelah usia kandungan 20 minggu yang disertai dengan proteinuria. ${ }^{3}$

WHO menemukan indikasi bahwa hipertensi menyebabkan kematian ibu sebanyak $14 \%$ di negara berkembang. ${ }^{4}$ Ada peningkatan insiden preeklampsia selama persalinan pada tahun 1987-2004 sebanyak 25\%. ${ }^{5}$ Pada tahun 2014, di Sumatra Barat, jumlah kematian ibu sebanyak 118 kasus dan jumlah tertinggi berada di Kota Padang yaitu sebanyak 16 kasus. Angka ini meningkat di Kota Padang pada tahun 2015 yaitu menjadi 17 orang. ${ }^{6}$ Berdasarkan laporan tahunan Dinas Kesehatan Kota Padang tahun 2015, dari 17 kasus kematian ibu di tahun tersebut, 23,5\% disebabkan oleh eklampsia. ${ }^{7}$

Pada ibu hamil dengan eklampsia terjadi hipertensi yang menyebabkan kelainan multisistem yang kompleks. Dalam beberapa tahun terakhir terdapat kontroversi mengenai pilihan teknik anestesia untuk sectio caesarea pada pasien dengan eklampsia. Menurut patofisiologi terjadinya eklampsia maka penggunaan anestesia spinal harus dipertimbangkan secara hati-hati karena secara teoritis memungkinkan terjadinya hipotensi tajam, penurunan curah jantung, dan hipoperfusi plasenta. Disisi lain, penggunaan anestesia umum juga memiliki berbagai risiko seperti kegagalan intubasi, aspirasi paru, fetal depresi terkait obat, perubahan tekanan darah selama laringoskopi dan intubasi, dan risiko pendarahan yang lebih besar pada pasien eklampsia. Setiap teknik anestesia memiliki cara kerja yang berbeda sehingga masingmasing memiliki keuntungan dan kerugian yang berbeda. 8

Pemberian anestesia pada ibu hamil untuk tindakan operasi obstetri maupun non-obstetri memberikan tantangan tersendiri bagi ahli anestesia. Tidak hanya memperhatikan keselamatan ibu dengan segala macam kemungkinan efek samping dan komplikasi yang muncul akibat perubahan anatomi dan fisiologi, namun juga memperhatikan bagaimana keselamatan janin. ${ }^{8}$ Sectio caesarea merupakan cara yang umum dilakukan pada ibu yang mengalami penyulit dalam melahirkan dan operasi ini terbukti telah menyelamatkan banyak nyawa ibu dan bayi. ${ }^{9}$ Terdapat dua teknik yang umum digunakan pada sectio caesarea yaitu anestesia umum dan anestesia regional yang terdiri dari anestesia spinal, epidural, atau gabungan teknik spinal-epidural. ${ }^{10}$

Anestesia umum dan anestesia spinal masingmasing memiliki cara kerja yang berbeda sehingga menyebabkan perubahan hemodinamik yang berbeda juga. Perubahan hemodinamik yang terjadi pada ibu akan mempengaruhi perfusi uteroplasental yang jika nilainya menurun memungkinkan terjadinya asfiksia neonatorum. Asfiksia pada neonatus dapat dinilai dengan penilaian APGAR. $^{9}$ Asfiksia neonatorum merupakan outcome neonatus yang dapat diketahui melalui penilaian APGAR yang dinilai pada menit pertama dan kelima. ${ }^{11}$ Menurut studi yang dilakukan Ehrenstein di Denmark, nilai APGAR yang rendah pada menit kelima berkaitan dengan beberapa kelaianan dan yang paling sering adalah kelaian neurologis seperti serebral palsy, epilepsi, kejang, dan gangguan kognitif. $^{12}$

Penelitian yang dilakukan oleh Mancuso et al di Italia menunjukkan terdapat perbedaan yang signifikan pada nilai persentase neonatus yang mengalami depresi, yaitu neonatus dengan nilai APGAR $<7$, antara kelompok anestesia spinal dengan kelompok anestesia umum. Penilaian APGAR pada menit kelima menujukan perbedaan yang signifikan dengan rata-rata nilai APGAR adalah sembilan pada kelompok anestesia umum dan sepuluh pada kelompok anestesia spinal. ${ }^{13}$

Penelitian lain yang dilakukan oleh Flora et. al., pada tahun 2014 di RS Dr. Hasan Sadikin Bandung. Penelitian ini mengamati perbandingan efek anestesia umum dengan anestesia spinal terhadap kejadian hipotensi dan nilai APGAR pada neonatus. Namun, pada penelitian ini hasil penilaian APGAR pada menit kelima menunjukan tidak terdapat perbedaan nilai yang 
bermakna antara kelompok anestesia umum dan anestesia spinal. Pada umumnya setelah lima manit bayi berada pada kondisi yang baik dengan nilai APGAR 8-10. ${ }^{14}$

Penelitian yang dilakukan oleh Silvia (2016) di RSUP DR. M. Djamil Padang menemukan bahwa sebanyak 57,5\% ibu dengan preeklampsia-eklampsia melahirkan secara sectio caesarea. Tingginya angka kejadian preeklamsia-eklampsia dari total jumlah persalinan di RSUP Dr. M. Djamil Padang disebabkan karena RSUP Dr. M. Djamil Padang adalah rumah sakit rujukan di Sumatera Barat. ${ }^{15}$

Berdasarkan uraian diatas, untuk mengindentifikasi pengaruh jenis anestesia terhadap output neonatus yang lahir dari ibu eklampsia maka perlu dilakukan penelitian untuk mengalisa hubungan jenis anestesia yang digunakan pada sectio caesarea dengan nilai APGAR.

\section{METODE}

Jenis penelitian ini adalah analitik dengan rancangan cross sectional yaitu subyek penelitian diobservasi sebanyak satu kali dan variabel diukur langsung pada pemeriksaan tersebut. ${ }^{16}$ Variabel independen adalah jenis anestesia dan variabel dependen adalah nilai APGAR. Penelitian dilakukan dari bulan Mei-Agustus 2019 di RSUP Dr. M. Djamil Padang.

Populasi penelitian ini adalah seluruh pasien eklampsia yang menjalani persalinan sectio caesarea di RSUP Dr. M. Djamil Padang selama periode 1 Januari 2015 - 31 Desember 2018.

Sampel penelitian ini diambil yang memenuhi kriteria inklusi dan tidak memiliki kriteria ekslusi. Kriteria inklusi subjek: lbu hamil dengan eklampsia yang dirawat dan melahirkan di RSUP dr. M.Djamil Padang periode 1 Januari 2015 - 31 Desember 2018. Kriteria eksklusi subjek: gawat janin, perdarahan antepartum, gemeli, polihidramnion, kehamilan dengan bayi cacat kongenital, kehamilan IUFD, penderita diabetes melitus. Sampel dibagi menjadi 2 kelompok yaitu kelompok anestesia umum dan kelompok anestesia spinal.
Data diperoleh dari catatan rekam medis dengan data yang diambil adalah usia pasien, usia kehamilan, paritas, status ASA, jenis anestesia, dan nilai APGAR. Data dianalisis secara statistik berdasarkan variabel yang dinilai menggunakan sistem komputerisasi yaitu analisis univariat dan bivariat. Analisis univariat dilakukan untuk melihat distribusi frekuensi dari masingmasing variabel independen dan variabel dependen. Analisis bivariat dilakukan untuk menganalisis komparatif antara dua kemopok. Uji komparatif tersebut dianalisis dengan menggunakan uji komparatif kategorik 2 kelompok tidak berpasangan yaitu uji Kolmogorov-Smirnov dan dikatakan bermakna bila $p<$ 0.05 .

\section{HASIL}

Hasil penelitian ini mendapatkan 131 pasien eklampsia selama periode 1 Januari 2015 sampai 31 Desember 2018 melalui data rekam medik pasien. penelitian dilakukan terhadap 63 pasien yang memenuhi kriteria inklusi dan tidak memiliki kriteria eksklusi. Pasien dibagi menjadi 2 kelompok, yaitu kelompok anestesia umum 33 pasien dan kelompok anestesia spinal 30 pasien.

\section{Gambaran Umum Angka Kejadian dan Karakteristik Pasien}

Tabel 1. Angka kejadian eklampsia di RSUP Dr. M. Djamil Padang periode 2015 - 2018

\begin{tabular}{|c|c|c|}
\hline Tahun & $f$ & $\%$ \\
\hline 2015 & 16 & 12,0 \\
\hline 2016 & 40 & 30,6 \\
\hline 2017 & 45 & 34,4 \\
\hline 2018 & 30 & 23,0 \\
\hline Jumlah & 131 & 100,0 \\
\hline
\end{tabular}

Berdasarkan Tabel 1 dapat dilihat bahwa terdapat 131 pasien eklampsia di RSUP Dr. M. Djamil Padang periode 2015 - 2018. Angka kejadian tertinggi terjadi pada tahun 2017 sebayak 45 kasus, sedangkan angka kejadian terendah terjadi pada tahun 2015 sebanyak 16 kasus. 
Tabel 2. Karakteristik pasien eklampsia di RSUP Dr. M. Djamil Padang

\begin{tabular}{lcccc}
\hline karakteristik & \multicolumn{2}{c}{$\begin{array}{c}\text { Kelompok Umum } \\
(\mathbf{n}=\mathbf{3 3})\end{array}$} & \multicolumn{2}{c}{$\begin{array}{c}\text { Kelompok Spinal } \\
(\mathbf{n}=\mathbf{3 0})\end{array}$} \\
\cline { 2 - 5 } & $\mathbf{f}$ & $\%$ & $\mathbf{f}$ & $\%$ \\
\hline Usia & & & & \\
$<20$ & 5 & 15,2 & 1 & 3,3 \\
$25-35$ & 25 & 75,8 & 21 & 70 \\
$>35$ & 3 & 9,1 & 8 & 26,7 \\
Usia kehamilan & & & & \\
$20-27$ & 1 & 3,0 & 0 & 0 \\
$28-32$ & 5 & 15,1 & 7 & 23,3 \\
$33-37$ & 18 & 54,6 & 16 & 53,4 \\
$>37$ & 9 & 27,3 & 7 & 23,3 \\
Paritas & & & & \\
Primipara & 17 & 51,5 & 11 & 26,7 \\
Multipara & 16 & 48,5 & 19 & 63,3 \\
Status ASA & & & & \\
2 & 1 & 3,0 & 8 & 26,7 \\
3 & 30 & 90,9 & 22 & 73,3 \\
4 & 2 & 6,1 & 0 & 0 \\
\hline
\end{tabular}

Berdasarkan Tabel 2, karakteristik umur distribusi paling tinggi berada pada rentang usia 20-35 tahun sebanyak 46 (73\%) orang, sedangkan yang terendah pada rentang $<20$ tahun sebanyak $6(9,5 \%)$ orang. Pada karakteristik paritas kebanyakan merupakan multipara sebanyak 35 (55,5\%) orang. Pada karakteristik usia kehamilan, usia kehamilan terendah adalah 27 minggu dan usia keshamilan tertinggi adalah 40 minggu, mayoritas usia kehamilan pada kategori preterm (<37 minggu) sebanyak 47 (74,6\%) orang. Pada karakteristik status ASA distribusi paling banyak terdapat pada ASA 3 sebanyak 52 $(82,5 \%)$ orang dan terendah pada ASA 4 sebanyak 2 $(3,2 \%)$ orang.

Perbandingan Nilai APGAR Bayi antara Kelompok Anestesia Umum dengan Kelompok Anestesia Spinal

Tabel 3. Perbandingan nilai APGAR menit pertama

\begin{tabular}{lccccccc}
\hline $\begin{array}{c}\text { Nilai } \\
\text { APGAR }\end{array}$ & $\begin{array}{c}\text { Umum } \\
(\mathbf{n}=\mathbf{3 3})\end{array}$ & \multicolumn{2}{c}{$\begin{array}{c}\text { Spinal } \\
(\mathbf{n}=\mathbf{3 0})\end{array}$} & \multicolumn{2}{c}{$\begin{array}{c}\text { Jumlah } \\
(\mathbf{n}=63)\end{array}$} & Nilai $\mathbf{p}$ \\
\cline { 2 - 6 } & $\mathrm{f}$ & $\%$ & $\mathrm{f}$ & $\%$ & $\mathrm{f}$ & $\%$ & \\
\hline $0-3$ & 12 & 36,4 & 3 & 10,0 & 15 & 23,8 & $<0,01$ \\
$4-6$ & 20 & 60,6 & 9 & 30,0 & 29 & 46,0 & \\
$7-10$ & 1 & 3,0 & 18 & 60,0 & 19 & 30,2 & \\
Jumlah & 33 & 100 & 30 & 100 & 63 & 100 & \\
\hline
\end{tabular}

Berdasarkan Tabel 3 dapat dilihat bahwa pada menit pertama kebanyakan bayi memiliki nilai APGAR yang rendah (APGAR1<7) yaitu sebanyak 29 (46\%) bayi dan secara umum kelompok anestesia spinal memperoleh nilai APGAR yang lebih tinggi. Hasil uji statistik menggunakan uji Kolmogorov-smirnoff menunjukkan bahwa terdapat perbadaan yang bermakna antara ibu anestesia umum dengan ibu anestesia spinal ( $p<0,05$; OR 48,0; $\mathrm{Cl} 4,5,76-399,5)$.

Tabel 4. Perbandingan nilai APGAR menit kelima

\begin{tabular}{lccccccc}
\hline $\begin{array}{c}\text { Nilai } \\
\text { APGAR }\end{array}$ & $\begin{array}{c}\text { Umum } \\
(\mathbf{n}=\mathbf{3 3})\end{array}$ & \multicolumn{2}{c}{$\begin{array}{c}\text { Spinal } \\
(\mathbf{n}=\mathbf{3 0})\end{array}$} & Jumlah & Nilai p \\
\cline { 2 - 6 } & $\mathrm{f}$ & $\%$ & $\mathrm{f}$ & $\%$ & $\mathrm{f}$ & $\%$ & \\
\hline $0-3$ & 1 & 3,0 & 0 & 0 & 1 & 1,6 & 0,02 \\
$4-6$ & 17 & 51,5 & 5 & 16,7 & 22 & 34,9 & \\
$7-10$ & 15 & 45,5 & 25 & 83,3 & 40 & 63,5 & \\
\hline
\end{tabular}

Berdasarkan Tabel 4 dapat dilihat bahwa pada menit kelima secara umum kondisi bayi sudah membaik dan kebanyakan bayi sudah tidak mengalami asfiksia yaitu sebanyak 40 (63,5\%) bayi dan secara umum kelompok anestesia spinal memperoleh nilai APGAR yang lebih tinggi. Hasil uji statistik menggunakan uji Kolmogorov-smirnoff menunjukkan bahwa terdapat perbadaan yang bermakna antara bayi anestesia umum dengan ibu anestesia spinal ( $p<0,05$; OR 6,0 ; Cl 1,8418,5).

\section{PEMBAHASAN}

Penelitian ini sejalan dengan yang dilakukan oleh Mancuso et al yang mendapatkan bahwa terdapat perbedaan yang signifikan pada nilai persentase neonatus yang mengalami asfiksia $($ APGAR $<7$ ) antara kelompok anestesia spinal dengan kelompok anestesia umum. ${ }^{13}$ Penelitian yang dilakukan oleh Algert et al yang meneliti perbandingan nilai APGAR bayi sectio caesarea dengan tiga tingkatan risiko yang berbeda juga menunjukan terdapat perbedaan yang bermakna pada nilai APGAR bayi yang lahir melalui sectio caesarea dengan anestesia umum dan anestesia spinal dimana bayi kelompok anestesia spinal secara umum memiliki nilai APGAR yang lebih baik dibandingkan dengan kelompok anestesia umum. ${ }^{17}$

Berdasarkan uraian diatas meskipun sectio caesarea dilakukan dengan indikasi yang berbeda, 
pada umumnya anestesia spinal tetap memberikan luaran nilai APGAR yang lebih baik dibandingkan dengan anestesia umum. Hal ini diakibatkan karena pada anestesiaa umum, sebagian besar obat yang dipergunakan (sedasi dan juga analgetik) memiliki berat molekul serta derajat ionisasi rendah, kelarutan dalam lemak yang tinggi, dan juga terikat pada protein secara tidak sempurna sehingga dapat memasuki barier plasenta dan berefek pada bayi, sedangkan kebutuhan obat pada tindakan anestesia spinal sangat sedikit sehingga pengaruh pada bayi dapat diabaikan. ${ }^{14}$

Hasil penelitian ini menunjukan bahwa pada umumnya bayi yang lahir dari ibu eklampsia pada umumnya akan mengalami asfiksia, temuan ini sejalan dengan penelitian yang dilakukan oleh Mohan et al yang menemukan bahwa eklampsia dapat meningkatkan risiko asfiksia neonatorum. ${ }^{18} \mathrm{Hal}$ ini sesuai dengan teori yang diungkapkan oleh Cunningham (2018) bahwa disfungsi endotel akan mengakibatkan gangguan keseimbangan antar kadar hormon vasokonstriktor (endotelin, tromboksan, angiotensin) dan vasodilator (nitritoksida, prostasiklin). ${ }^{19}$ Vasokonstriksi pembuluh darah mengakibatkan kurangnya suplai darah ke plasenta sehingga terjadi hipoksia janin. Akibat lanjut dari hipoksia janin adalah gangguan pertukaran gas antara oksigen dan karbon dioksida sehingga terjadi asfiksia neonatorum. Pengembangan paru bayi baru lahir terjadi pada menit-menit pertama kemudian disusul dengan pernapasan teratur dan tangisan bayi. Proses perangsangan pernapasan ini dimulai dari tekanan mekanik dada pada persalinan, disusul dengan keadaan penurunan tekanan oksigen arterial dan peningkatan tekanan karbon dioksida arterial, sehingga sinus karotikus terangsang sehingga terjadi proses bernapas. Bila mengalami hipoksia akibat suplai oksigen ke plasenta menurun karena efek hipertensi dan proteinuria sejak intrauterin, maka saat persalinan maupun pasca persalinan beresiko asfiksia. ${ }^{3}$

Pada awal proses kelahiran setiap bayi akan mengalami hipoksia relatif dan akan terjadi adaptasi akibat aktivitas bernapas dan menangis. Apabila proses adaptasi terganggu, maka bayi bisa dikatakan mengalami asfiksia yang akan berefek pada gangguan sistem organ vital seperti jantung, paru-paru, ginjal dan otak yang mengakibatkan kematian. ${ }^{3}$ Nilai APGAR menit pertama memberi gambaran kemampuan bayi untuk melakukan toleransi terhadap proses kelahiran, dan juga menunjukkan bahwa bayi yang baru lahir ini membutuhkan perhatian medis lebih lanjut, namun belum tentu mengindikasikan akan terjadi masalah jangka panjang, khususnya jika terjadi peningkatan nilai pada menit kelima, ${ }^{14}$ sedangkan nilai APGAR menit kelima memberikan penilaian seberapa jauh bayi dapat beradaptasi dengan lingkungannya yang baru, dan juga merupakan indeks yang lebih tepat tentang kemungkinan kematian bayi dan atau sekuele neurologik. ${ }^{20}$ Nilai APGAR menit kelima yang kurang dari 4 merupakan prediktor yang kuat terhadap kematian bayi. Risiko kematian neonatus pada saat APGAR menit kelima adalah 0,2/1.000 pada bayi dengan nilai APGAR 7-10, sedangkan pada bayi dengan nilai APGAR 0-3 adalah 244/1.000. ${ }^{21}$ Telah dilaporkan risiko yang akan meningkat untuk terjadinya kejang, keterlambatan perkembangan mental, epilepsi, cerebral palsy, perdarahan intrakranial pada nilai APGAR 5 menit di bawah $7 .{ }^{12}$

\section{SIMPULAN}

Terdapat perbedaan yang bermakna antara penggunaan anestesia umum dan anestesia spinal terhadap nilai APGAR bayi yang lahir melalui sectio caesarea dari ibu eklampsia.

\section{SARAN}

Bagi peneliti selanjutnya disarankan melakukan penelitian lebih lanjut dengan karaktristik sampel yang lebih spesifik sehingga tidak menimbulkan bias pada hasil penelitian. Selain itu, perlu juga penambahan variabel lain yang dapat mempengaruhi luaran bayi seperti incision delivery interval, kejadian hipotensi selama operasi, dan penggunaan obat-obat anestesia yang digunakan selama operasi.

\section{UCAPAN TERIMAKASIH}

Penulis telah banyak mendapatkan bantuan dan dukungan dari berbagai pihak, oleh karena itu pada kesempatan ini penulis ingin menyampaikan rasa hormat dan terimakasih kepada seluruh pihak yang membantu seluruh pihak yang membantu sehingga penelitian ini dapat diselesikan dengan baik. 


\section{DAFTAR PUSTAKA}

1. Balogun OAA, Sibai BM. Counseling, management, and outcome in women with severe preeclampsia at 23 to 28 weeks' gestation. Clin Obstet Gynecol. 2017;60(1):183-9.

2. Herrera CA, Silver RM. Perinatal asphyxia from the obstetric standpoint: diagnosis and interventions. Clin Perinatol. 2016;43(3):423-38.

3. Angsar M. IImu kebidanan Sarwono Prawirohardjo. 4th ed. Jakarta: PT Bina Pustaka Sarwono Prawirohardjo; 2010.hlm. 530-61.

4. World Health Organization (WHO). Global causes of maternal death: a WHO systematic analysis. Lancet Glob Health. 2014;2:322-33.

5. Jeyabalan A. Epidemiology of preeclampsia: impact of obesity. Nutr Rev. 2013;71(1):S18-25.

6. Dinas Kesehatan Provinsi Sumatera Barat. Profil Kesehatan Provinsi Sumatera Barat 2014; 2015. 154.

7. Dinas Kesehatan Kota Padang. Laporan tahunan tahun 2015; 2016. 121.

8. Imtiaz A, Mustafa $S$, Masroorudin, Ulhaq N, Ali $\mathrm{SH}$, Imtiaz K. Effect of spinal and general anaesthesia over APGAR score in neonates born after elective cesarean section. J Liaquat Univ Med Heal Sci. 2010;9(3):151-4.

9. Afolabi B, Lesi A, Merah N. Regional versus general anaesthesia for caesarean section. cochrane Collab. 2010;35(4):40-8.

10. Jauniaux E, Grobman WA. Textbook of Caesarea Section. 1st ed. Oxford: Oxford University Press; 2016.hlm. 37,102-3.

11. Wahidayat I, Sastroasmoro S. Pemeriksaan Fisis Neonatus. Dalam: Kresnawati W. editor. Pemeriksaan Klinis pada Bayi dan Anak. Edisi ke3. Jakarta: Sagung Seto; 2017.hlm.153-67.

12. Ehrenstein V. Association of Apgar scores with death and neurologic disability. Clin Epidemiol. 2010;9(1):45-53.

13. Mancuso A, Vivo A De, Giacobbe A, Priola V, Savata LM, Guzzo M, et al. General versus spinal anaesthesia for elective caesarean sections: effects on neonatal short-term outcome. A prospective randomised study. J Matern Neonatal Med. 2010;23(10):1114-8.

14. Flora L, Redjeki IS, Wargahadibrata $\mathrm{AH}$. Perbandingan Efek Anestesia Spinal dengan Anestesia Umum terhadap Kejadian Hipotensi dan Nilai APGAR Bayi pada Seksio Sesarea. Anestesia Perioper. 2014;2(024):105-16.

15. Silvia P. Gambaran luaran perinatal pada ibu preeklampsia-eklampsia di RSUP DR M Djamil Padang [skripsi]. Padang: Universitas Andalas Fakutas Kedokteran; 2016.

16. Sugiyono PD. Metode penelitian kuantitatif, kualitatif, dan R\&D. Bandung: Alfabeta; 2016.hlm. 187-91.

17. Algert CS, Bowen JR, Giles WB, Knoblanche GE, Lain SJ, Roberts CL. Regional block versus general anaesthesia for caesarean section and neonatal outcomes: a population-based study. BMC Med. 2009;7(5):1-7.

18. Mohan K, Mishra PC, Singh DK. Clinical profile of birth asphyxia in newborn. 2013;3(1):10-9.

19. Cunningham FG, Leveno KJ, Bloom SL, Dashe JS, Hofman BL, Casey BM, et al. Williams Obstetrics. 25th ed. New York: The McGraw-Hill Companies; 2018. 567-8.

20. American Academy of Pediatrics, Amrican College of Obstetricians and Gynecologists. The Apgar score. Am Coll Obstet Gynecol. 2017;(644):4.

21. Casey BM, Mclntire DD, Leveno KJ. The continuing value of the apgar score for the assessment of newborn infants. Obstet Gynecol Surv. 2001;56(7):406-7. 